\title{
SPRAWOZDANIA Z DZIAŁALNOŚCI KRAKOWSKICH GIMNAZJÓW JAKO ŹRÓDŁO DO BADAŃ DZIEJÓW BIBLIOTEKARSTWA SZKOLNEGO W 1. POŁOWIE XX WIEKU (NA PRZYKŁADZIE II PAŃSTWOWEGo GiMNAZJUM I LICEUM IM. ŚW. JACKA)
}

Jadwiga Filipkowska-Szemplińska w artykule opublikowanym w 1929 roku w czasopiśmie "Przegląd Biblioteczny” ${ }^{1}$, pisząc o roli książki w życiu młodego człowieka, stwierdziła: Zbliżenie dziecka z książka, wytworzenie u niego nawyków do obcowania z nia i pokazanie, ile ciekawego materjału może z niej zaczerpnąć, musi uskutecznić szkoła za pośrednictwem bibljoteki ${ }^{2}$. Cytat ten pojawia się we wstępie nieprzypadkowo, doskonale bowiem nawiązuje do działań, które podejmowały krakowskie gimnazja na przełomie XIX i XX wieku, aby zapewnić uczniom dostęp do książek.

Przyjmując kryteria klasyfikacji bibliotek do poszczególnych ich rodzajów, zastosowane $\mathrm{w}$ ankiecie rejestracji placówek bibliotecznych w 1930 roku przez Wydział Oświaty Pozaszkolnej Ministerstwa Wyznań Religijnych i Oświecenia Publicznego, a przywołane przez Jana Muszkowskiego w artykule z 1935 roku, książnice gimnazjalne (podobnie jak pozostałe szkolne, a także naukowe i wojskowe) zostały zaliczone do bibliotek oświatowych szkolnych, podczas gdy inne wypożyczalnie i czytelnie udo-

${ }^{1}$ J. Filipkowska-Szemplińska, Organizacja bibljotek szkolnych oraz znaczenie ich $w$ wychowaniu młodzieży, „Przegląd Biblioteczny” 1929, nr 13, s. 303-304. O bibliotekarstwie szkolnym w I połowie wieku XX tej autorki również: Organizacja bibljotek szkolnych, Warszawa 1930; H. Falkowska, Z dziejów polskich bibliotek szkolnych, Warszawa 1966.

2 J. Filipkowska-Szemplińska, Organizacja..., s. 303. 
stępniające dzieła beletrystyczne tworzyły grupę placówek oświatowych pozaszkolnych ${ }^{3}$.

Na przełomie XIX i XX wieku istniało w Krakowie 11 gimnazjów: Państwowe Gimnazjum i Liceum św. Anny ${ }^{4}$ - I, Państwowe Gimnazjum i Liceum im. św. Jacka - II ${ }^{5}$, Państwowe Gimnazjum i Liceum im. Jana III Sobieskiego - III $^{6}$, Państwowe Gimnazjum i Liceum im. Henryka Sienkiewicza - IV 7 , Państwowe Gimnazjum i Liceum im. Jana Kochanowskiego - V ${ }^{8}$, Państwowe Gimnazjum i Liceum im. Tadeusza Kościuszki - VI ${ }^{9}$, Państwowe Gimnazjum i Liceum im. Bartosza Głowackiego - VII ${ }^{10}$, Państwowe Gimnazjum i Liceum im. Augusta Witkowskiego - VIII ${ }^{11}$, Państwowe Gimnazjum i Liceum im. J. Hoene-Wrońskiego - IX ${ }^{12}$, Państwowe Gimnazjum i Liceum Żeńskie im. Królowej Wandy - X ${ }^{13}$, Państwowe Gimnazjum i Liceum Żeńskie im. Józefy Joteyko - XI ${ }^{14}$, a w każdej ze szkół istniała bibliote$\mathrm{ka}$ - mniej lub bardziej zasobna, jedna lub podzielona na oddziały.

${ }^{3}$ J. Muszkowski, Bibljoteki oświatowe $w$ Polsce [w:] Książka w pracy oświatowej, Warszawa 1935, s. 26-47.

${ }^{4}$ Najstarsze z nich - Gimnazjum św. Anny, sięga tradycjami do roku 1617, kiedy to Bartłomiej Nowodworski przeznaczył pewne fundusze na pensje dla profesorów. Szkoła po różnych kolejach losu przetrwała do dziś i obecnie nosi nazwę I Liceum Ogólnokształcącego im. Bartłomieja Nowodworskiego w Krakowie. (Encyklopedia Krakowa, red. prow. A. H. Stachowski, Kraków 2000, s. 547).

${ }^{5}$ II Państwowe Gimnazjum i Liceum im. św. Jacka (1857-1915), obecnie VI Liceum Ogólnokształcące im. A. Mickiewicza (Encyklopedia Krakowa, s. 242-243).

${ }^{6}$ III Państwowe Gimnazjum i Liceum im. Jana III Sobieskiego, obecnie II Liceum Ogólnokształcące im. Króla Jana III Sobieskiego (Encyklopedia Krakowa, s. 547).

7 IV Państwowe Gimnazjum i Liceum im. Henryka Sienkiewicza, nazywane także Gimnazjum Goetza, mieszczące się w kamienicy przy ul. Podwale, istniało w latach 1901-1947 (Encyklopedia Krakowa, s. 951).

${ }^{8}$ V Państwowe Gimnazjum i Liceum im. Jana Kochanowskiego, obecnie III Liceum Ogólnokształcące im. Jana Kochanowskiego (Encyklopedia Krakowa, s. 547).

9 VI Państwowe Gimnazjum i Liceum im. T. Kościuszki, obecnie IV Liceum Ogólnokształcące im. Tadeusza Kościuszki (Zob.: Kalendarium [online] [dostęp: 20.05.2014]. Dostępny WWW: http://iv-lo.krakow.pl/jubileusz/kalendarium.php).

${ }^{10}$ VII Państwowe Gimnazjum i Liceum im. Bartosza Głowackiego, obecnie obecnie Gimnazjum nr 7 im. Bartosza Głowackiego w Krakowie (Zob.: Gimnazjum nr 7 w Krakowie [online]. [dostęp: 20.05.2014] Dostępny WWW: http://www.gim7krakow.oswiata.org.pl/?m=kronika; Encyklopedia Krakowa, s. 951).

${ }^{11}$ VIII Państwowe Gimnazjum i Liceum im. Augusta Witkowskiego, obecnie V Liceum Ogólnokształcące im. Augusta Witkowskiego (Encyklopedia Krakowa, s. 547).

12 IX Państwowe Gimnazjum i Liceum im. J. Hoene-Wrońskiego (Encyklopedia Krakowa, s. 951)

${ }^{13}$ X Państwowe Gimnazjum i Liceum Żeńskie im. Królowej Wandy (Encyklopedia Krakowa, s. 951).

${ }^{14}$ XI Państwowe Gimnazjum i Liceum im. J. Joteyko (1938-1962). 
Aby ukazać funkcjonowanie tych jednostek szkolnych, posłużono się przykładem biblioteki Gimnazjum św. Jacka - szkoły istniejącej w krakowskim środowisku edukacyjnym niemalże 100 lat (1857-1950) ${ }^{15}$. Założone w 1857 roku przez władze austriackie, rozpoczęło działalność rok później, oferując naukę w języku niemieckim. Nie cieszyło się jednak dużą popularnością wśród uczniów ${ }^{16}$, dlatego też zostało przekształcone na gimnazjum polskie, czteroklasowe, a następnie w 1868 roku nazwane imieniem św. Jacka i przemianowane na wyższe II Gimnazjum św. Jacka, ośmioklasowe. Szkoła bardzo dobrze prosperowała, dlatego w 1902 roku powstała jej filia przy ul. Sebastiana $10^{17}$. W 1932 roku, zgodnie z założeniami reformy szkolnictwa, została podzielona na czteroletnie gimnazjum i dwuletnie liceum. W czasie II wojny światowej, po utracie budynku zajętego przez wojska niemieckie, naukę kontynuowano na tajnych kompletach organizowanych w budynku V Liceum i Gimnazjum przy ul. Jana Kochanowskiego ${ }^{18}$. Po wojnie szkoła wznowiła działalność w poprzedniej formie, jednak już w 1948 roku przekształcono ją w liceum ogólnokształcące. W 1950 roku szkołę zamknięto, a sześć lat później próbowano ją reaktywować - bezskutecznie.

W budynku przy ul. Siennej, po zajęciu go przez wojska niemieckie, pozostały dwie osoby - Stanisław Szeligiewicz (dyrektor) i Maksymilian Olejak (woźny). Ich obecność przyczyniła się do tego, że większa część zbiorów naukowych, w tym biblioteki, ocalała. Narażając życie własne i swoich pomocników, M. Olejak zdążył ukryć wiele z przyrządów i pomocy naukowych w mieszkaniach profesorów i rodziców uczniów, zanim hitlerowcy zajęli budynek, zaś w zakamarkach budynku ukrył sztandar szkoły, bibliotekę, zbiory historyczno-geograficzne, rzeźby, zbiory do nauki przyrody, fizyki $i$ katalogi klasowe ${ }^{19}$. Z kolei dyrektor przechował w swoim mieszkaniu sprawozdania szkolne, akta szkoły i przyrządy szkolne, które po wojnie zwróciła Wanda Szeligiewiczowa, wdowa ${ }^{20}$.

${ }^{15}$ Ogólny zarys funkcjonowania krakowskich bibliotek gimnazjalnych przedstawiła Maria Stinia w podrozdziale: Biblioteki szkolne [w:] taż, Państwowe szkolnictwo gimnazjalne w Krakowie w okresie autonomii galicyjskiej, Kraków 2004, s. 204-220.

${ }^{16}$ W 1865 roku uczęszczało do niego 88 uczniów (Mała encyklopedia Krakowa, Kraków 1996, s. 433).

17 Oddział główny II Gimnazjum mieścił się kolejno w budynkach przy ul. Kanoniczej, Siennej i Grzegórzeckiej. Filia w 1902 roku została przekształcona w VI Liceum Ogólnokształcące im. Adama Mickiewicza, które istnieje do dziś.

${ }_{18}$ Z dziejów II Państwowego Gimnazjum i Liceum im. św. Jacka w Krakowie 1857-1950, Kraków 1967, s. 13.

19 Tamże, s. 15.

${ }^{20}$ Tamże. 
W wyniku II wojny światowej większość ze 100 szkół (średnie, zawodowe i powszechne), które istniały w roku szkolnym 1939/40, poniosła straty w księgozbiorach. Szacunkowo przyjmuje się, że utracono nie mniej niż 113000 tomów, a poszczególne rodzaje szkół od 50 do 80\% zawartości bibliotek $^{21}$. Z bibliotek gimnazjalnych najbardziej ucierpiały księgozbiory I PGiL im. B. Nowodworskiego oraz III PGiL im. Króla Jana III Sobieskiego $^{22}$, spalone na dziedzińcach szkolnych ${ }^{23}$, VI PGiL im. T. Kościuszki - straciło wszystkie 6441 tomów ${ }^{24}$ oraz IX PGiL im. J. Hoene-Wrońskiego, które utraciło 98\% zasobu (7313 z 7440 wol.) $)^{25}$; V PGiL im. Jana Kochanowskiego - straciło 4345 z 4815 (90\%) ${ }^{26}$; VIII PGiL im. A. Witkowskiego - straciło 5469 z 5721 (96\%) ${ }^{27}$; X PGiL im. Królowej Wandy - straciło wszystkie $4000^{28}$. Dla innych księgozbiorów los był łaskawszy: IV PGiL im. H. Sienkiewicza - utraciło szacunkowo 30\%, nie znamy stanu sprzed wojny ${ }^{29}$; VII PGiL im. A. Mickiewicza - z 4700, 2000 stracono $(43 \%)^{30}$. II PGiL im. św. Jacka utraciło 53\% swoich zbiorów, które przed wojną liczyły 4510 wol., 2119 wol. zostało po wojnie ${ }^{31}$. Pojedyncze przykłady starych druków pochodzących z krakowskich bibliotek gimnazjalnych zachowały się w Pedagogicznej Bibliotece Wojewódzkiej im. Hugona Kołłątaja, utworzonej w 1922 roku placówce Okręgu Szkolnego Krakowskiego ${ }^{32}$. Przykład ten nie jest jednak odosobniony - Maria Strutyńska w artykule z 1993 roku przedstawiła stare druki o proweniencjach bibliotek gimnazjalnych w Chojnicach i Chełmnie znajdujące się w bibliotece Uniwersytetu Mikołaja Kopernika w Toruniu ${ }^{33}$.

${ }^{21}$ P. Lechowski, Straty bibliotek Krakowa podczas II wojny światowej [w:] Symposia bibliologica: dokumentacja księgozbiorów historycznych - wspótpraca krajowa i międzynarodowa, Skutki II wojny światowej dla bibliotek polskich / [red. tomu H. Łaskarzewska, red. nauk. A. Mężyński], Warszawa 1995, s. 180.

${ }^{22}$ Biblioteka liczyła przed wojną 10000 woluminów. Zob.: Straty bibliotek $w$ czasie II wojny światowej w granicach Polski z 1945 roku: wstępny raport o stanie wiedzy, cz. 1-2, oprac. B. Bieńkowska, Warszawa 1994, s. 210.

23 Tamże, s. 179.

${ }^{24}$ Tamże, s. 213.

25 Tamże, s. 210.

26 Tamże, 213.

27 Tamże.

${ }^{28}$ Tamże.

29 Tamże, s. 210.

${ }^{30}$ Tamże, s. 213.

31 Por. P. Lechowski, Biblioteki Krakowa w okresie okupacji niemieckiej 1939-1945, Kraków 1999, s. 44-47.

${ }^{32}$ Są to m.in. Corneliusa Neposa Vitae excellentium imperatorum observationibus, Amstelodami 1707 - z pieczątką Biblioteki Nauczycielskiej Gimnazjum św. Jacka.

${ }_{33}$ M. Strutyńska, Stare druki bibliotek gimnazjalnych Chojnic i Chetmna w zbiorach biblioteki Uniwersytetu Mikołaja Kopernika [w:] Bibliologia dyscyplina integrujaca, Warszawa 1993, s. 127-137. 
Jako materiał źródłowy ${ }^{34}$ do przedstawienia tematu wykorzystano 55 sprawozdań dyrekcji II Gimnazjum im. św. Jacka - z lat 1871, 1872, 18761925/1926 i 1934/1935-1936/1937, z których metodą ekscerpcji źródła wyodrębniono grupę treści związanych z biblioteką i bibliotekarstwem. Pewnym kłopotem metodologicznym związanym ze statystykami jest zmieniająca się forma podawania informacji dotyczących biblioteki szkolnej. Artykuł zawiera analizę danych dotyczących głównej jednostki II Gimnazjum i Liceum Ogólnokształcącego. Pamiętać należy, że w 1902 roku utworzono filię przy ul. Sebastiana, której tradycje kontynuuje dziś krakowskie VI Liceum Ogólnokształcące im. Adama Mickiewicza. Księgozbiór filii będzie tematem oddzielnego opracowania ${ }^{35}$.

Sprawozdanie C.K. Dyrekcyi Gimnazyalnej św. Jacka w Krakowie wydawane po zakończeniu każdego roku szkolnego składało się (w prawie wszystkich rocznikach) ze stałych części. Rozpoczynała je ${ }^{36}$ rozprawa naukowa autorstwa jednego z profesorów gimnazjum ${ }^{37}$, po niej zaś następowała część sprawozdawcza, rozpoczynająca się od przedstawienia grona pedagogicznego, kroniki działalności szkoły oraz wykazu uczniów, rozkładu przedmiotów w poszczególnych klasach i tematów prac pisemnych. Następnie przedstawiano zbiory szkoły wraz z określeniem nowych nabytków. Całość kończyły wyniki z matury. W większości z przeanalizowanych dokumentów znajduje się także wykaz zalecanych podręczników lub przeczytanych lektur, informacja o stypendiach i nagrodach ${ }^{38}$.

Treści związane z biblioteką można podzielić na kilka grup: ludzie - zawiadowcy ${ }^{39}$, pomocnicy, darczyńcy i użytkownicy; finanse - braki, dotacje, pozyskiwanie; normalizacja - przepisy zewnętrzne i wewnętrzne; statystyka - gromadzenie, ilość zbiorów. Na podstawie tych informacji można częściowo odtworzyć podstawowe procesy biblioteczne w ówczesnych placówkach - gromadzenie, opracowanie, struktura, przechowywanie i udostępnianie zbiorów.

${ }^{34}$ O źródłach do badań bibliologicznych zob.: J. Puchalski, Źródła do historii bibliotek $w$ Polsce w latach 1918-1947: studium bibliologiczne, Warszawa 2007; K. Migoń, Problematyka źródłoznawcza w bibliologii, „Studia o Książce”, 1985, t. 15, s. 3-18; M. Mlekicka, Wykorzystanie źródeł drukowanych z lat 1795-1918 do badań nad dziejami książki polskiej. Zarys metodologiczny, „Z badań nad polskimi księgozbiorami historycznymi” 1977, z. 3, s. 23-56.

${ }^{35}$ Po raz pierwszy wzmianka o bibliotece filialnej pojawia się w sprawozdaniu z roku 1903.

${ }^{36}$ Na podstawie Sprawozdania z roku 1871 (w dalszej części Spr. Dyr. II PGiL i rok)

$37 \mathrm{~Np}$. w sprawozdaniu z roku szkolnego 1871 był to tekst $O$ weglowcach $z$ uwzględnieniem węgli kopalnych w Wielkiem Księstwie Krakowskiem autorstwa Karola Klęska - nauczyciela historii naturalnej, członka Towarzystwa Naukowego Krakowskiego.

38 Spr. Dyr. II PGiL 1916 r.

${ }^{39}$ W żadnym ze sprawozdań nie pojawia się termin „bibliotekarz”. Nauczyciele pełniący funkcję opiekuna / kierownika biblioteki szkolnej nazywani są zawiadowcami. 
Wiadomości o bibliotece, zawsze wymienianej w gronie zbiorów naukowych, były przedstawiane $\mathrm{w}$ różnej formie i zawierały rozmaite treści, co umożliwia podanie jedynie przybliżonych danych liczbowych. W najstarszym przedstawionym sprawozdaniu jest to np. informacja, iż w roku 1871 nabyto 97 dzieł oraz wymienienie ich w formie krótkich opisów, zawierających tytuł i autora. W sprawozdaniu z 1872 roku odnotowano konkretne sygnatury, które zasiliły bibliotekę (655-734), by z kolei w 1876 roku podać szczegółowe dane liczbowe już trzech funkcjonujących w Gimnazjum św. Jacka bibliotek: nauczycieli ${ }^{40}$, uczniów, książek szkolnych dla ubogich uczniów ${ }^{41}$, liczących kolejno 1523 tomy, 780 tomów i 272 tomy, oraz wyszczególnienia według działów przybytków w bibliotece nauczycieli, np. z filozofii i pedagogii - trzy tytuły w trzech tomach, innej treści - cztery książki w dziewięciu tomach; bibliotece uczniów - 13 dzieł w 25 tomach, bibliotece w języku niemieckim - 11 tytułów w 31 tomach, oraz do zbioru książek dla ubogich uczniów - 102 tomy. Tak szczegółowe zapisy znalazły się również w dwóch następnych sprawozdaniach, natomiast rocznik 1879 nie podaje informacji o bibliotece szkolnej. Od roku 1880 dokładne informacje statystyczne, z podziałem na działy książek, zostały zastąpione przez statystyki ogólne. Oceniano ilość ksiażek, które trafiły do poszczególnych bibliotek i ich obecny stan inwentarzowy. Rok 1884 to kolejne zmiany - nowe nabytki klasyfikowano do dwóch grup: zakupy i dary. W późniejszych latach sprawozdania były coraz bardziej szczegółowe, np. w roku 1910 w działalności „Pomocy bratniej” przedstawiono rozliczenie finansowe jednostki - ile zarobiono na wypożyczaniu książek (były to symboliczne opłaty), ile było darów pieniężnych i ile należy zapłacić Krzyżanowskiemu ${ }^{42}$ za zakup podręczników dla uczniów z ubogich rodzin.

${ }^{40}$ O księgozbiorach nauczycielskich w szkołach zob.: J. Dzieniakowska, Szkolne biblioteki dla nauczycieli [w:] Państwowe biblioteki dla nauczycieli w Drugiej Rzeczypospolitej: studium historyczno-bibliologiczne, Kielce 2009, s. 317-383.

${ }^{41}$ Taki podział księgozbioru obowiązywał w większości szkół w Polsce. Przykładowo w utworzonym w roku szk. 1921/1922 gimnazjum polskim w Cieszynie poszczególne zbiory posiadały w roku szk. 1926/27: biblioteka nauczycielska - 724 tomy, biblioteka uczniów polska - 738 tomów, biblioteka uczniów niemiecka - 234 tomy, podręczniki dla ubogich uczniów - 1102 tomy. (Por. np.: H. Zeprzałka, Biblioteki szkolne na Śląsku Cieszyńskim w świetle sprawozdań szkolnych (1850-1939) [w:] Książka - biblioteka - szkoła w kulturze Śląska Cieszyńskiego: materiały z konferencji naukowej, Cieszyn 4-5 listopada 1999, pod red. J. Spyry, Cieszyn 2001, s. 350).

${ }^{42}$ Stanisław Andrzej Krzyżanowski (1836-1922) - krakowski księgarz i wydawca. Zob.: A. Ruta, Księgarnia „S.A. Krzyżanowski” w Krakowie. Zarys dziejów: 1870-1950, Kraków 2003. 


\section{Struktura}

W sprawozdaniu z roku 1871, najstarszym dostępnym, pojawia się jedynie informacja o nabytkach do biblioteki, podczas gdy już rok później mamy jej podział na trzy zbiory - bibliotekę nauczycieli (1523 t.), bibliotekę uczniów (780 t.) i zbiór książek szkolnych dla ubogich uczniów (272t.). Z kolei w 1876 roku biblioteka uczniów została przedstawiona jako dwa odrębne działy - książek w języku polskim i książek w języku niemieckim ${ }^{43}$. W roku 1906 w sprawozdaniu pojawia się informacja o czytelni, która, poza oferowaniem zbiorów do korzystania na miejscu, stała się także centrum spotkań naukowych, działalności kółek zainteresowań zrzeszających chętnych uczniów.

Mówiąc o księgozbiorach, dodać należy, że poza wymienionymi, wyodrębnionymi, szkoła posiadała także podręczne zbiory materiałów naukowych (w tym książek) przynależne do konkretnych pracowni naukowych (geograficznej, historycznej itd.).

\section{Ludzie}

Na próżno szukać w sprawozdaniach słowa „bibliotekarz”. We wcześniejszych dokumentach nazwisko zawiadowcy zamieszczano po części opisowej biblioteki. W późniejszych zaś w wykazie nauczycieli gimnazjum, rozpoczynającym część sprawozdawczą, gdzie przy kilku nazwiskach zaznaczano odpowiedzialność za poszczególne biblioteki, używając terminu „zawiadowca”. Przykładowo w bilansie z roku 1883 zawiadowcą biblioteki był Karol Brzeziński - nauczyciel historii i geografii, zbiorami niemieckojęzycznymi dla uczniów opiekował się Feliks Baczakiewicz - nauczyciel języka niemieckiego, księgozbiorem polskojęzycznym dla uczniów - Wawrzyniec Waśkowski, nauczyciel języka polskiego i historii. Z kolei w roku 1908 funkcje zawiadowców pełnili: Jan Jakóbiec (nauczyciel języka niemieckiego i filozofii) - biblioteka nauczycielska, Juliusz Trzciński (nauczyciel łaciny i języka polskiego) - biblioteka polska dla uczniów, Piotr Jaworek (nauczyciel języków polskiego i niemieckiego) - biblioteka niemiecka dla uczniów, Franciszek Chowaniec (nauczyciel języka greckiego) - biblioteka pomocy koleżeńskiej. W dwóch sprawozdaniach pojawia się zapis o zaangażowaniu uczniów w prace biblioteczne: Przy wypożyczaniu książek chętnie i gorliwie

${ }^{43}$ Język niemiecki w początkowych latach działalności gimnazjum był jedynym i obowiązującym, stopniowo jednak pojawiał się język polski jako wykładowy, natomiast księgozbiór stawał się podstawą do nauczania języka niemieckiego. 
pomagali uczniowie kl. VII b, Suchecki Maksymilian i Żmija Antoni ${ }^{44}$. O popularności i randze biblioteki świadczą także koła naukowe działające w ramach jej struktury. 10 listopada 1906 roku otworzono czytelnię, w której swą działalność rozpoczęły kółko naukowo-literackie (15 członków) i przyrodnicze (8 członków) ${ }^{45}$. W kolejnych latach dołączyły jeszcze koła historyczne, naukowo-wychowawcze oraz sekcja reprodukcyjno-fotograficzna. Jednym z przejawów ich działalności były spotkania naukowe, w trakcie których zaproszeni profesorowie lub uczniowie wygłaszali referaty. W czytelni swoją działalność rozwijała także pomoc koleżeńska i antykwarnia, umożliwiająca zakup używanych podręczników i lektur szkolnych.

\section{Finanse i gromadzenie}

Podstawą powiększania zbiorów bibliotek gimnazjum były zakupy, w mniejszym stopniu prenumerata oraz dary zarówno od osób prywatnych (zazwyczaj nauczycieli i uczniów), jak i instytucji. Wśród tych drugich największą liczbę zbiorów przekazała Akademia Umiejętności.

Do roku 1878 dotacje na cele biblioteczne przekazywało Wysokie Ministerstwo Wyznań i Oświecenia, jednak rozporządzenie z dnia 6 lipca tego roku $^{46}$ zniosło subwencje, nakazując, aby przy wpisach do szkoły od każdego ucznia żądać po 1 złr., przeznaczając zdobyte w ten sposób fundusze na powiększanie zbiorów naukowych. Od tej pory w większości sprawozdań, w końcowej części, kierowanej od dyrekcji do rodziców, pojawiał się zapis, iż każdy uczeń złoży 1 złr. ${ }^{47}$ na środki naukowe ${ }^{48}$. Od roku 1900 składka wynosiła $2 \mathrm{k}^{49}$, natomiast od 1919 roku Rada Szkolna Krajowa rozporządzeniem z 11 czerwca tegoż roku ${ }^{50}$ podniosła jej wysokość do $5 \mathrm{k}$. Kilka lat wcześniej, w roku 1912, gimnazjum otrzymało od ministerstwa nadzwyczajną dotację w wysokości 4000 k na zakup środków naukowych ${ }^{51}$.

Oddzielne źródło finansowania miała biblioteka pomocy koleżeńskiej, gromadząca podręczniki szkolne wypożyczane za niewielką opłatą uczniom pochodzącym z niezamożnych rodzin. Główne dochody na zakupy stanowi-

\footnotetext{
${ }^{44}$ Identyczne notatki w sprawozdaniach z roku 1909 (s. 83) i 1910 (s. 77).

45 Spr. Dyr. II PGiL 1907 r., s. 111-112.

${ }^{46}$ Spr. Dyr. II PGiL 1879 r., s. 68.

${ }^{47} \mathrm{Złr}$ - gulden austro-węgierski zwany też złotym reńskim, waluta obowiązująca w latach 1857-1892; 1 złr = 100 krajcarów.

48 Spr. Dyr. II PGiL 1879 r., s. 39.

${ }^{49} \mathrm{~K}$ - korona austro-węgierska, waluta obowiązująca w latach 1892-1918; $1 \mathrm{k}=100$ halerzy.

${ }^{50}$ Spr. Dyr. II PGiL 1919 r., s. 39.

${ }^{51}$ Spr. Dyr. II PGiL 1912 r., s. 181.
} 
ły właśnie owe opłaty oraz dary pieniężne (najczęściej profesorów i uczniów). W 1876 roku liczyła ona 272 tomy, w 1880 - 300 tomów, w 1906 - 558 książek szkolnych. W kolejnych sprawozdaniach rzadko pojawia się informacja o liczbie zbiorów, natomiast niemalże w każdym z nich odnotowano kwotę, jaką wydano na uzupełnienie zasobu. Przykładowo w roku 1899 - $156 \mathrm{k}$ 80 h na pomoc koleżeńską, w tym na książki ${ }^{52}$, w roku 1904 - więcej o 61 podręczników za $132 \mathrm{k} 11$ h ze składek i drobnych opłat za wypożyczenie ${ }^{53}$, w 1906 roku - Franciszek Chowaniec zakupił książki szkolne za kwotę 47 k 34 h, Franciszek Gołba na książki szkolne wydał 50 k 60 h, dyrektor Ignacy Kranz za Wypisy niemieckie dla kl. V - 7 K 60 h, w księgarni Krzyżanowskiego zapłacono za książki szkolne $239 \mathrm{k} 76 \mathrm{~h}^{54}$.

Pomocne $\mathrm{w}$ odpowiedniej polityce gromadzenia księgozbioru były niewątpliwie zalecenia ministerialne - wykazy książek, które zostały dopuszczone do użytku szkolnego. W roku 1883 były to Deutsches Lehr- und Lesebuch Georga Harwota, Dzieje powszechne skrócone, cz. I-III, Zygmunta Sawczyńskiego (wyd. 4), czasopisma „Kosmos”, „Przewodnik Bibliograficzny" oraz publikacje wydawane nakładem Macierzy Polskiej ${ }^{55}$. W roczniku wcześniejszym opublikowano listę książek, które zabrania się rozpowszechniać w bibliotekach szkolnych ${ }^{56}$. Z kolei w sprawozdaniu z roku 1890 zamieszczono odezwę Wysokiej Rady Szkolnej Krajowej z 30 kwietnia 1890 roku (l. 7223) w sprawie przesyłania przez nauczycieli wykazu publikacji stosownych dla młodzieży gimnazjalnej ${ }^{57}$.

Biblioteka prowadziła także prenumeratę czasopism i wydawnictw ciągłych. Pierwsza informacja pojawia się w sprawozdaniu z 1884 roku i mówi o 14 tytułach, m.in. „Szkoła”, „Ateneum”, „Biblioteka Warszawska” i „Zeitschrift für das Realschulwesen, Repertorium der Physik”. Dwa lata później prenumerowano już 19 tytułów, w 1894 roku - 12 tytułów, w 1916 roku - tylko 9.

${ }^{52}$ Spr. Dyr. II PGiL 1889 r., s. 91

53 Spr. Dyr. II PGiL 1904 r., s. 78.

${ }^{54}$ Spr. Dyr. II PGiL 1906 r., s. 98.

${ }^{55}$ Macierz Polska - założone we Lwowie w 1882 roku towarzystwo oświatowe, które poprzez tanie wydania starało się docierać z wiedzą do mniej zamożnych warstw społecznych. Zob.: D. Adamczyk, Edukacja historyczna w wydawnictwach dla ludu na przykładzie „Macierzy polskiej” w latach 1882-1914/18 [w:] Państwo - wieś - kultura, pod red. J. Sztejnbis-Zbyb, R. Turkowskiego, Warszawa 2011, s. 305-313; D. Adamczyk, Literatura piękna w wydawnictwach dla ludu na przykładzie lwowskiego wydawnictwa „Macierz Polska” (1882-1914/1918) [w:] Książka, biblioteka, informacja: między podziałami a wspólnota, pod red. J. Dzieniakowskiej, Kielce 2007, s. 73-79; J. Szocki, Ksiązka popularna dla ludu (na przykładzie „Macierzy Polskiej” 1883-1920) [w:] Książka i prasa w systemie komunikacji społecznej, pod red. M. Judy, Lublin 2002, s. 61-67).

${ }^{56}$ Spr. Dyr. II PGiL 1882 r., s. 37.

57 Spr. Dyr. II PGiL 1890 r., s. 57. 


\section{Przepisy $^{58}$}

Prace biblioteki Gimnazjum św. Jacka regulowały przepisy wewnętrzne i zewnętrzne. Do pierwszych należał regulamin, którego fragmenty zamieszczano w sprawozdaniach. I tak w latach 1882 i 1883 pojawiła się notatka: Książki wzięte $z$ biblioteki zwracać należy w przepisanym czasie i to całe, bez uszkodzenia. Uszkadzanie lub zanieczyszczanie sprzętów szkolnych nie może uchodzić bezkarnie ${ }^{59}$. Kilka lat później odnotowano 10. paragraf z Przepisów szkolnych dla uczniów szkót krakowskich, który brzmiał: Książki wypożyczone z biblioteki szkolnej zwracać należy w przepisanym czasie i nieuszkodzone. Uczeń, który opuszcza zakład w ciągu roku, powinien natychmiast zwrócić wypożyczone książki ${ }^{60}$.

Drugą grupę regulacji stanowią rozporządzenia władz, zamieszczane w dziale Ważniejsze rozporzadzenia wysokich władz szkolnych. W roku 1886 są to trzy akty: Okólnik Wysokiej Rady Szkolnej Krajowej z 25 lipca 1885 roku w sprawie inwentarzy zbiorów naukowych ${ }^{61}$, Reskrypt Wysokiego Ministerstwa Wyznań i Oświaty z dn. 11 grudnia 1885 roku w sprawie obowiązkowego przesyłania po jednym egzemplarzu programu bibliotekom uniwersyteckim w Austrii ${ }^{62}$, oraz Reskrypt Wysokiego Ministerstwa Wyznań i Oświaty z 16 grudnia tegoż roku w sprawie rewizji bibliotek szkolnych dla młodzieży. W roku kolejnym Wysoka Rada Szkolna Krajowa okólnikiem z 30 maja 1887 roku informuje o reskrypcie Ministra Wyznań i Oświecenia z 2 kwietnia 1887 roku w sprawie urządzenia i uzupełniania biblioteki szkolnej dla uczniów ${ }^{63} .27$ listopada tego roku WMWiO wydało z kolei rozporządzenie ${ }^{64}$ nakazujące usunięcie ze szkół i bibliotek uczniowskich książek pod względem typograficznym nieodpowiednich ${ }^{65}$.

Bilans z roku 1889 przynosi regulację w związku z inwentarzami bibliotecznymi. WRSzK rozporządzeniem z 17 listopada 1888 roku nakazuje, by dyrekcje szkół do końca roku 1890 przygotowały inwentarze zbiorów na-

${ }^{58} \mathrm{O}$ regulacjach prawnych bibliotekarstwa szkolnego w XX-leciu międzywojennym por.: M. Olczak-Kardas, Biblioteki uczniowskie szkót powszechnych w Polsce w latach 1918-1939, „Studia Bibliologiczne Akademii Świętokrzyskiej” 2005, t. 9, s. 181-194.

59 Spr. Dyr. II PGiL 1882 r., s. 75; Spr. Dyr. II PGiL 1883 r., s. 2.

${ }^{60}$ Spr. Dyr. II PGiL 1890 r., s. 71.

${ }^{61}$ Spr. Dyr. II PGiL 1886 r., s. 70.

62 Tamże.

${ }^{63}$ Spr. Dyr. II PGiL 1887 r., s. 102.

${ }^{64}$ Tamże.

${ }^{65}$ Spr. Dyr. II PGiL 1888 r., s. 81. 
ukowych w trzech egzemplarzach i jeden $\mathrm{z}$ nich przekazały WRSzK ${ }^{66}$. Kilka lat później, w 1897 roku, WMWiO aktem prawnym z 30 grudnia 1896 roku normuje zalecenia związane z prenumeratą czasopism przez biblioteki oraz drukowaniem katalogów biblioteki nauczycielskiej ${ }^{67}$. Rok później Wysoka Cesarsko-Królewska Rada Szkolna rozporządzeniem z 4 listopada 1897 roku wprowadza poprawki do zaleceń związanych z drukowaniem katalogów bibliotecznych w sprawozdaniach szkolnych ${ }^{68}$. Drukowany katalog, zawierający 1817 sygnatur, zostaje zamieszczony w kolejnym sprawozdaniu ${ }^{69}$.

\section{Zbiory i statystyka}

Podanie dokładnych statystyk jest niemożliwe, ponieważ sprawozdania nie miały jednolitej formy. Najbardziej kłopotliwy okazał się brak konsekwencji w wykazach tytułów i tomów, tym samym część sprawozdań zawiera informację o liczbie dzieł, część o liczbie tomów. Jednoznacznie jednak można stwierdzić, że biblioteka stale powiększała swój zasób, z czasem wyodrębniając z niego dwa zbiory - dla nauczycieli oraz dla uczniów (ten podzielony na polsko- i niemieckojęzyczny). Trzecim księgozbiorem była biblioteka pomocy koleżeńskiej, ciesząca się dużą popularnością wśród uczniów. Wybrane dane statystyczne przedstawiają się następująco. W sprawozdaniu z roku 1872 dyrekcja informuje o nowych nabytkach, odnotowanych pod sygnaturami 655-734, co oznacza, że w roku 1871 biblioteka liczyła 654 wydawnictwa. Cztery lata później (1876) są już wydzielone trzy księgozbiory - biblioteka nauczycieli (1523 t.), biblioteka uczniów (780 t.) i biblioteka pomocy dla ubogich uczniów (272 t.). Kolejne podsumowania w sposób szczegółowy wyliczają, ile dzieł i w ilu tomach przybyło w poszczególnych zbiorach, co świadczy o tym, że były one przechowywane zgodnie z tematyką, np. w 1877 roku do działu filozofii klasycznej przybyło 11 dzieł w 12 tomach, nauk przyrodniczych -6 dzieł w 9 tomach itd. W roku 1892 biblioteka nauczycieli liczyła już 2317 publikacji w 4324 tomach i 41 zeszytach, dla uczniów 684 dzieła w 1103 tomach $^{70}$. Z kolei w 1911 roku poinformowano, że do zbioru nauczycieli zakupiono 28 tytułów, otrzymano 8 tytułów i prenumerowano 2 tytuły, zaś dla młodzieży

${ }^{66}$ Spr. Dyr. II PGiL 1889 r., s. 69.

67 Spr. Dyr. II PGiL 1897 r., s. 115.

68 Spr. Dyr. II PGiL 1898 r., s. 63.

${ }^{69}$ Katalog biblioteki nauczycielskiej c.k. gimnazyum św. Jacka w Krakowie [w:] Spr. Dyr. II PGiL 1899 r., s. 1-50.

${ }^{70}$ Spr. Dyr. II PGiL 1892 r., s. 81. 
Wykres 1. Przyrost księgozbioru polskojęzycznego dla uczniów w latach 1897-1905

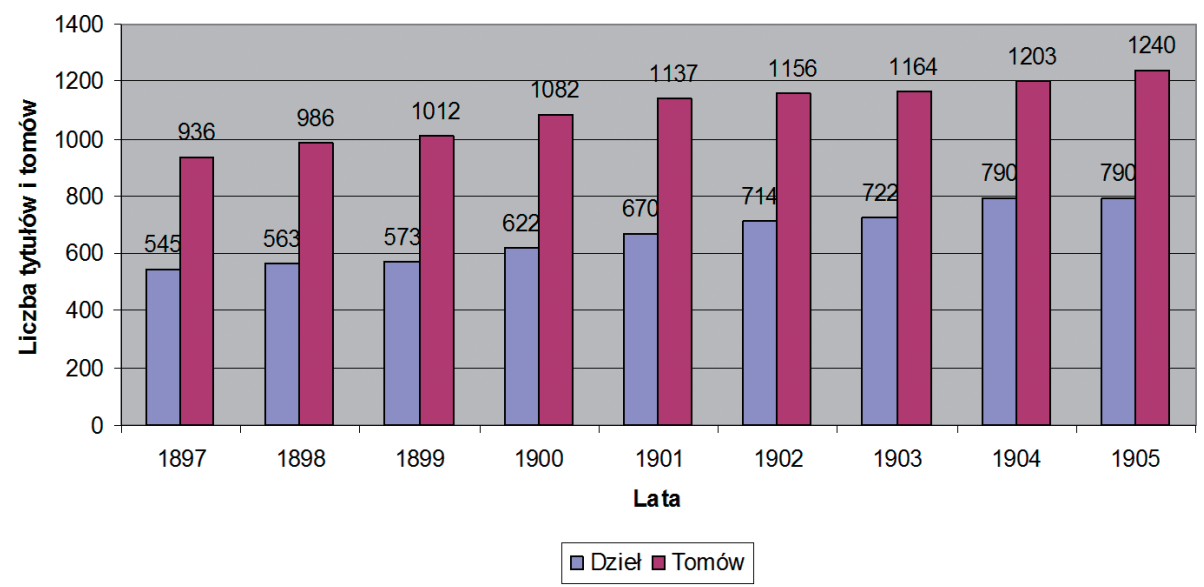

Źródło: Opracowanie własne.

zakupiono 27 tytułów. Przykładowe powiększanie się księgozbioru polskojęzycznego dla uczniów przedstawia wykres 1 .

Rok szkolny 1920/21 przynosi opis zawartości biblioteki: Pomoc naukowa: Zakład posiada bibljotekę nauczycielska, mieszcząca się $w$ dwóch szczupłych pokoikach, a obejmujaca 5000 dzieł, bibljotekę dla uczniów polska (1400 dziet) i niemiecka (751 dzieł), osobny zbiór programów szkolnych (9600 sztuk), zbiory do nauki historji i geografi (296 pozycji), zbiory przyrodnicze (1970 pozycji) i fizykalne (666 pozycji), zbiory do nauki rysunków (300 okazów), gabinet archeologiczny (295 pozycji) i zbiór nut do śpiewu $(130 \text { utworów })^{71}$.

Zgromadzone materiały biblioteczne bywały przemieszczane między poszczególnymi bibliotekami gimnazjum. Przykładowo w 1903 roku z księgozbioru uczniowskiego do nauczycielskiego przeniesiono 6 tytułów, rok później 9 tytułów, w kolejnym roku - 3 tytuły, w 1908 - 10 tytułów. Organizując zbiory czytelni, również wzbogacano ją o wydawnictwa z bibliotek uczniowskiej i nauczycielskiej

W związku z tym, że w 1922 roku biblioteki gimnazjalne musiały przekazać część swoich zbiorów do nowo powstałej Biblioteki Okręgu Szkolnego Krakowskiego, w dwóch sprawozdaniach (1922/23 i 1923/24) zamieszczono

${ }^{71}$ Spr. Dyr. II PGiL 1920/21 r., s. 6. 
krótkie, jednakowo brzmiące notatki: Bibljotekę nauczycielska wcielono do Bibljoteki centralnej, pozostawiając tylko podręczniki szkolne $e^{72}$. W tym czasie biblioteka uczniów liczyła 1450 książek, niemiecka - 751 książek, programy szkolne - 9600 publikacji (w obu sprawozdaniach te same dane). Bilanse z lat przedwojennych nie zawierają statystyk bibliotecznych.

Tylko jedno sprawozdanie, z roku 1899, zawiera całościowy obraz jednej z bibliotek należących ówcześnie do gimnazjum, mianowicie Katalog biblioteki nauczycielskiej c.k. gimnazyum św. Jacka w Krakowie ${ }^{73}$. Odnotowano w nim, zgodnie z zaleceniami Wysokiej Cesarsko-Królewskiej Rady Szkolnej (rozporządzenie z 4 listopada 1897 roku wprowadzające poprawki do zaleceń związanych $\mathrm{z}$ drukowaniem katalogów bibliotecznych w sprawozdaniach szkolnych), 1817 sygnatur w XIV działach: I. Encyklopedya - sygn. 1-82, II. Filozofia i Estetyka - sygn. 83-193, III. Pedagogia i Szkolnictwo - sygn. 194-376, IV. Religia - sygn. 377-398, V. Filologia klasyczna - sygn. 399-766, VI. Filologia nowoczesna - sygn. 767-1141, VII. Lingwistyka - sygn. 1142-1184, VIII. Geografia, Etnografia, Statystyka - sygn. 1185-1302, IX. Historya powszechna - sygn. 1303-1590, X. Historya austr.-węg. Monarchii - sygn. 1591-1606, XI. Matematyka - sygn. 1607-1652, XII. Historya naturalna - sygn. 1653-1835, XIII. Fizyka - sygn. 1736-1811, XIV. Budownictwo, Inżynierya - 1812-1817 ${ }^{74}$. Na uwagę załuguje fakt, że biblioteka posiadała co najmniej 67 starych druków: XVI-wiecznych - 2, XVII-wiecznych - 7, i XVIII-wiecznych - 58.

\section{Udostępnianie}

Od roku szkolnego 1900/1901 zamieszczano w sprawozdaniach informacje dotyczące aktywności czytelników. W latach 1900/1901-1905/1906 przedstawiono dane z biblioteki polskiej dla uczniów. I tak najwięcej wypożyczono w pierwszym roku - 2017 tytułów w 2399 tomach, najmniej w roku ostatnim - 1501 tytułów w 2013 tomach, średnia z tych sześciu lat to 1672 tytuły w ciągu roku. Od roku 1908 zmieniono rodzaj zapisu, podając ilość uczniów i ilość książek, przy czym największą aktywnością charakteryzuje się rok 1909 - 309 uczniów i 2370 książek, najmniejszą rok 1916 - 167 uczniów i 1016 książek, średnia z dziewięciu lat (1908-1914, 1916-1917) wynosi 217 uczniów i 1582 książki tylko dla księgozbioru polskojęzycznego.

\footnotetext{
${ }^{72}$ Spr. Dyr. II PGiL 1922/23 r., s. 9; Spr. Dyr. II PGiL 1923/24 r., s. 9.

${ }^{73}$ Katalog biblioteki... (por. przypis nr 66).

${ }^{74}$ Tamże.
} 
Wykres 2. Statystyka wypożyczeń księgozbioru niemieckojęzycznego dla uczniów w latach 1908-1914

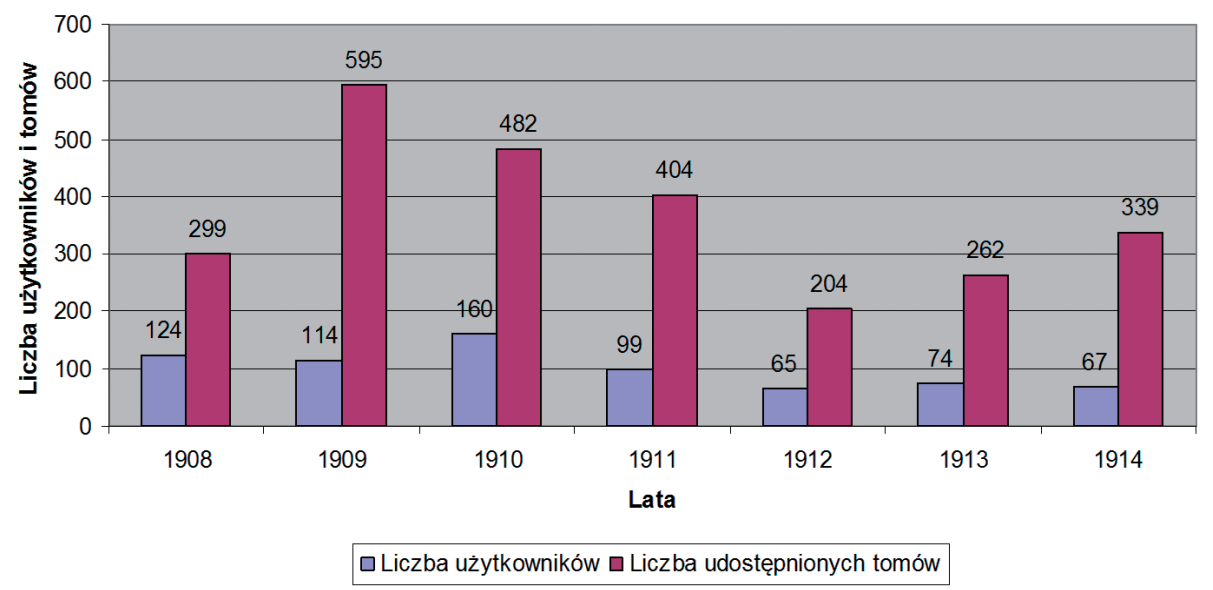

Źródło: Opracowanie własne.

Również w tych latach podano statystyki czytelnictwa dla zasobu niemieckojęzycznego, wykazując, że najlepszy pod względem liczebności aktywnych uczniów był rok 1910 - 160, pod względem wypożyczonych książek rok 1909 - 595. Średnio w ciągu dziewięciu lat z tego zbioru skorzystało 94 uczniów, którzy wypożyczyli łącznie 338 książek (por. wykres 2).

Utworzony w 1906 roku specjalny księgozbiór czytelni liczył 220 tomów dzieł naukowych i beletrystycznych, które zostały wydzielone z biblioteki nauczycielskiej. Otwarta była ona około 2-3 godzin popołudniami w tygodniu, natomiast $\mathrm{w}$ niedziele i święta po porannej mszy świętej. Zbiory sukcesywnie powiększano, dodając kolejne publikacje z biblioteki nauczycielskiej i uczniowskiej, a także dokonując niewielkich zakupów i prenumerat. Przykładowe średnie statystyki odwiedzin mówią o 25 uczniach w roku 1907, 30 w roku 1908, 22 w roku 1909, zaś zmienność frekwencji tłumaczono w sprawozdaniu z 1908 roku następująco: w letnich (miesiącach - AFK) zaś zmniejszała się w odwrotnym stosunku do podnoszenia się temperatur ${ }^{75}$.

W okresie I wojny światowej sprawozdania zawierały niewiele informacji związanych z biblioteką. Były to dane zawiadowców poszczególnych zbiorów (bez biblioteki nauczycielskiej) oraz dane finansowe dotyczące opłat za

${ }^{75}$ Spr. Dyr. II PGiL 1908 r., s. 76. 
wypożyczanie książek i wydatków na zakupy podręczników do zbioru pomocy koleżeńskiej. W 1915 roku dyrekcja informowała: Dla braku jednak miejsca i czasu (...) nie mogły też funkcjonować biblioteki, ani Czytelnia, ani Kółka naukowe uczniów ${ }^{76}$; trzy lata później: Podaje do wiadomości wskazówki c.k. Ministerstwa w. i o., jak oszczędzać opatu, zabrania opalać bibliotek, gabinetów i t.d. (27/9 1917 L. 27.793/IV) $)^{77}$.

Podczas działań II wojny światowej część zbiorów udało się uratować dzięki staraniom dyrektora gimnazjum - S. Szeligiewicza - i woźnego M. Olejaka. Jednak utracono 53\% zbiorów - przed II wojną światową liczyły one 4510 wol. Tradycje gimnazjum kontynuuje VI Liceum Ogólnokształcące im. Adama Mickiewicza, powstałe z filii II gimnazjum w 1902 roku.

Analiza wybranego przykładu sprawozdań jednej z 11 placówek gimnazjalnych pokazała, jak cennym materiałem badawczym nad stanem bibliotek i bibliotekarstwem przełomu XIX i XX wieku oraz 1. połowy XX wieku są sprawozdania dyrekcji, zwłaszcza że większość istniejących wówczas szkół utraciła nie tylko zbiory biblioteczne, ale także niemalże całą ich dokumentację (np. Gimnazjum im. Nowodworskiego, Gimnazjum im. Jana III Sobieskiego). Dzięki danym zawartym w sprawozdaniach możemy ustalić nie tylko szacunkową wielkość zbiorów, lecz także przedstawić sposoby ich pozyskiwania, fundusze biblioteczne, przepisy, strukturę, zawartość i wykorzystanie.

\section{Abstract \\ Reports on the activities of Cracow secondary schools as a source for the study of history school librarianship in the first half of the twentieth century (for example II National Middle School and High School named St. Jack)}

In Cracow, in the first half of the twentieth century, worked eleven main middle schools, each of which had its own library, often accumulated already in the nineteenth century or earlier. For example, saved printed reports (55 yearbooks) management of II National Middle School and High School named St. Jack (1857-1950) in the text an attempt is made to present the activities of the school library. The content associated with it were divided into several groups: people, finance, standardization, statistics. Based on this information, we can recreate some basic processes in contemporary educational library - collections, preparation, structure, store and share collections.

\footnotetext{
${ }^{76}$ Spr. Dyr. II PGiL 1915 r., s. 55.

77 Spr. Dyr. II PGiL 1918 r., s. 30.
} 